\title{
On the Dating of the Ethiopian Dynastic Treatise Kabrä nägäśt: New Evidence
}

\author{
Serge A. Frantsouzoff \\ Institute of Oriental Manuscripts, Higher School of Economics (St. Petersburg), \\ St. Petersburg State University \\ serge.frantsouzoff@yahoo.fr
}

\begin{abstract}
The present article argues the garbled text of the Lev. 18:8 as found in the Ethiopian dynastic treatise Kabrä nägäśt to be intentional. It refers to the conflict between the King of Ethiopia 'Amdä Șəyon I (1314-1344) and the Däbrä Libanos monastic congregation. The author argues that the second half of that verse was deliberately changed in order to make the royal marriage of 'Amdä Șəyon I to a wife/concubine of his late father to be seen as the mother - son incest. The conflict took place in the $27^{\text {th }}$ year of the reign of 'Amdä Șəyon I. The new interpretation of the Lev. 18:8 as appears in the Kabrä nägäśt allows to attribute the treatise rather precisely: the terminus ante quem non can be set from the beginning of the 40 s of the 14 th century AD, i.e. somewhere in the $1340 \mathrm{~s}$.
\end{abstract}

\section{Keywords}

Ethiopian Christian state - monarchy and monasticism in medieval Ethiopia Solomonic dynasty - King 'Amdä Șəyon I - dynastic treatise Kabrä nägäśt - Ethiopic version of the Bible

* This article is an output of the research project "Minority and Majority in the Asian-African Area: 'Ethics' vs 'Efficiency' in the Context of Socio-Cultural Interaction," implemented as a part of the Basic Research Program at the National Research University Higher School of Economics (HSE). 
The Ethiopian dynastic chronicle Kabrä nägäśt, or the "Nobility of the Kings,"1 was written in Ge'ez language. One of its aims was to justify the right of descendants of the Biblical King Solomon and the Queen of Sheba to the supreme power in the Christian Ethiopia. Its precise attribution has since been one of the major topics in Ethiopian studies. Professor Sevir B. Chernetsov (1943-2005) had significantly contributed to this attribution. He saw Ya'əbikä Agzi', the hereditary ruler of the region Andärta in south-eastern Təgray in $1314-1322^{2}$ to be instrumental for the whole concept of this historical opus. Ya‘əbikä Ggzi' was soon removed from power by 'Amdä Șəyon I the King of Ethiopia (1314-1344), who made a full use of the concept for legitimization of the dynasty developed by his unhappy rival himself. It should be noted that the so-called Solomonic dynasty was founded by his grandfather the King Yəkunno Amlak in 1270 as a result of the coup d'État which overthrew the previous dynasty of Zagwe. ${ }^{3}$

The suggestions brought forward by the Russian Professor of Ethiopian Studies have been enthusiastically met by his colleagues all over the world. Being called as "a new and interesting approach" they were mentioned in full in the leading article of the international project Encyclopaedia Aethiopica. ${ }^{4}$ However, the debate on the exact date of transcription of the Kabrä nägäśt is not over. For example, a French Syrologist Muriel Debié some years ago saw in the chronicle "un apocryphe du vi ${ }^{\mathrm{e}}$ s. à la gloire du roi Caleb." ${ }^{5}$ According to Debié, the Kabrä nägäśt would have been written shortly after the HimyaroAksumite war which was unleashed to revenge for atrocities the Christian martyrs from the oasis of Nagrân suffered from by the Jewish King of Himyar Yosef (Masrûq). ${ }^{6}$ This suggestion as appeared in a reputable volume is at least surprising. One knows that the hagiographic tradition linked with the veneration

1 The traditional translation of that title as the "Glory of the Kings" is less accurate.

2 The name of that "righteous prince beloved by Lord" is found in the colophon to the treatise (Kebra Nagast: Die Herrlichkeit der Könige, hrsg. und mit deutscher Übersetzung versehen von C. Bezold (Abhandlungen der Königlichen Bayerlichen Akademie der Wissenschaften, I. Klasse, XXIII. Bd, I. Abt.), München, 1905, S. 172, Kol. 2.12-13).

3 С. Б. Чернецов, Эфиопская феодальная монархия в ХIII-XVII вв. (S. B. Chernetsov, The Ethiopian Feudal Monarchy in the 13th-16th centuries AD), Moscow, 1982, pp. 35-40.

4 P. Marrassini, "Kəbrä nägäśt," in: $E A E$, Vol. 3, 2007, pp. 365-366.

5 M. Debié, "Le Kebra Nagast éthiopien: une réponse apocryphe aux événements de Najran?," in: Juifs et chrétiens en Arabie aux ve et VI $I^{e}$ siècles: regards croisés sur les sources, éd. J. Beaucamp, Fr. Briquel-Chatonnet et Ch.J. Robin (Collège de France - CNRs. Centre de recherche d'histoire et civilisation de Byzance. Monographies 32. Le massacre de Najrân. Religion et politique en Arabie du Sud au vi ${ }^{\mathrm{e}}$ siècle, II), Paris, 2010, pp. 255-278, here p. 257.

6 M. Debié, "Le Kebra Nagast éthiopien". 
of the martyrs of Nagrân came to Ethiopia through the Christian Arabs. This is corroborated by the fact that the 'Martyrdom of St. Aretha' was translated into Ge'ez not directly from its Greek original, but from one of its Arabic versions. ${ }^{7}$ It is also known that the traces of an Arabic influence are transparent in the text of the Kabrä nägäśt. Among such traces should be noted numerous loanwords $^{8}$ and a specific, non Ge'ez syntax. ${ }^{9}$

The fact that the Kabrä nägäśt was transcribed at the time starting from the reign of 'Amdä Şəyon I is nowadays beyond any doubt. Fortunately this is quite possible to narrow this date by the information found the chapter XLII of the Kabrä nägäst called "On the Decalogue." There is an obvious alteration of the original text of the Scriptures (Lev. 18:8) with regard to the Biblical views on restrictions of sexual relations between relatives by blood as well as by marriage. The second half of the verse mentioned there, i.e. "The nakedness of thy father's wife shalt thou not uncover: it is thy father's nakedness" was changed. In the Kabrä nägäst it reads: "it is thy mother's nakedness" (

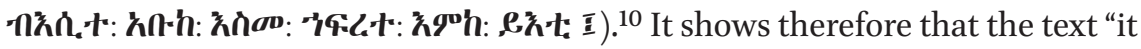
is thy mother's nakedness" used as an authoritative text from the Scriptures suggests that the violation of this commandment should be considered equal to an incest. It should be emphasized that such a textual garble is the only one

7 J. Beaucamp, Fr. Briquel-Chatonnet, Ch. J. Robin, "La persécution des chrétiens de Nagrân et la chronologie himyarite," Aram, 11-12 (1999-2000), pp. 15-83, here p. 27, n. 48.

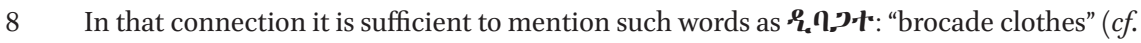

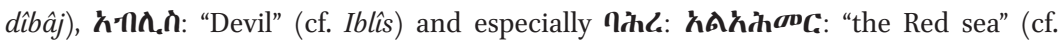
al-Baḥr al-Aḥmar) (Kebra Nagast, S. 33, Kol. 1.7; S. 81, Kol. 2.21; S. 61, Kol. 2.10).

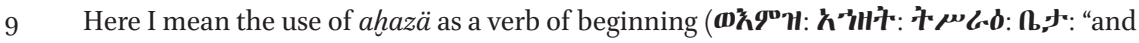
then the Queen of Sheba began to arrange her house (palace)", as well as the expression

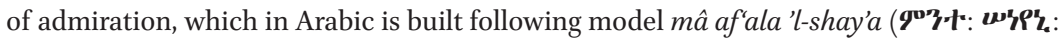
\$Ah:: - "How I like thy speech" (Kebra Nagast, S. 14, Kol. 2.21-22; S. 20, Kol. 1.21-22). The question on an Arabic prototype of the Kabrä nägäst, the existence of which is confirmed in its colophon (Kebra Nagast, S. 172, Kol. 1.9-20), which still remains open (Marrassini, "Kəbrä nägäśt," p. 367), is beyond the task of the present article.

10 Kebra Nagast, S. 43, Kol. 1.8-10. It should be stressed that in the Ethiopic translation of the Leviticus there are no deviations from the Masoretic text as well as that of the Lxx. The actual Biblical verse (in the Ethiopian tradition Lev. 18:7 but not the Lev. 18:8 as in the

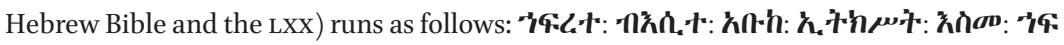

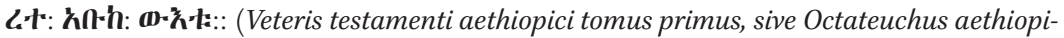

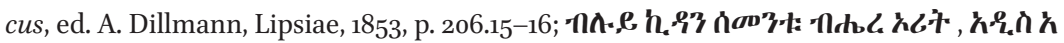

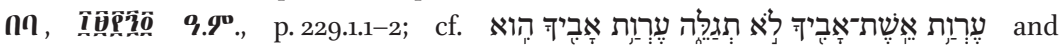

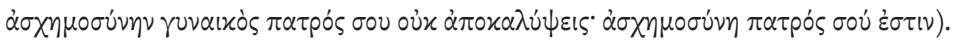


in the quotation of a rather large Biblical fragment (Lev. 18:5/6-15) included in the chapter XLII of the Kabrä nägäśt. ${ }^{11}$

The alteration of the Biblical text invites to see a reflection of the conflict, which took place between the King 'Amdä Șəyon I and the southern monastic congregation of Däbrä Libanos because of the increasing land acquisitions by the monasteries in South Ethiopia hindered by the King. In outward appearance this conflict took a shape of the condemnation of the monarch's polygamy by a number of clerics. The condemnation itself took place in the 27 th year of the reign ${ }^{12}$ of the King 'Amdä Șəyon I. It reached its pinnacle when the King for political reasons married one of his late father's concubines or wives. Then the clerics did even accuse him of incest because from the point of view of the ecclesiastical law this woman technically ranked to his mother.

Those condemnation found their reflection in other known texts. Thus the Life of St. Philip of Däbrä Libanos who was the second abbot of that monastery says: And when our Father Philip was staying in such a way, the men, who knew sorcery, seduced the king and said to the king whose name was 'Amdä Şyon: 'Take the wife of thy father. What does it matter to thee: in any case thou wilt not marry that who gave birth to thee. And we know that thy kingdom will persist, if thou marriest her, otherwise, it will not persist (

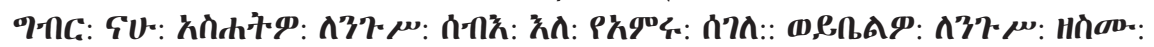

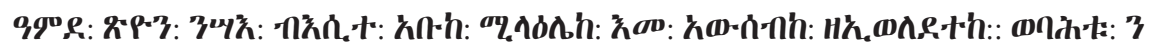

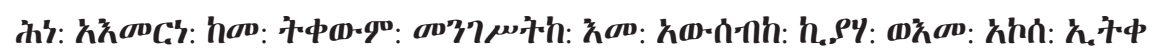
(D.qP::). ${ }^{13}$ There is no doubt that St Philip disapproved of the royal marriage and clearly accused the King of incest: And the king said to him: 'Be ashamed, oh monk!' And our Father Philip said to him: 'Be ashamed, thou who married the

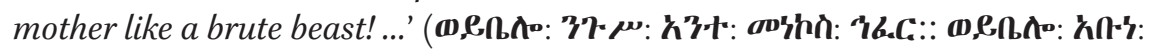

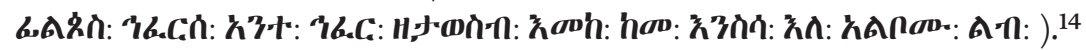

The so-called "Shorter Chronicle," which was also compiled in the monastic milieu, again re-iterates the charges against 'Amdä Șəyon I: Then in those days

11 Cf. Kebra Nagast, S. 43, Kol. 1.3-2.3.

12 Чернецов, Эфиопская феодальная монархия, pp. 54-56; J. Mantel-Niećko, D. Nosnitsin, “Amdä Səyon I," in: $E A E$, Vol. 1, 2003, pp. 228-229. It is interesting to note that Boris A. Turayev did not see any socio-economical background underlay this conflict. He wrote that "the noble defenders of Christian morals" among the monks of Däbrä Libanos "raised their voice against the lawless act of the king” (Б. А. Тураев, Исследования в области агиологических источников истории Эфиопии (В. A. Turayev, Studies in the Field of Hagiological Sources of the History of Ethiopia), St. Petersburg, 1902, p. 118).

13 Monumenta aethiopiae hagiologica, ed. B. Turaiev, fasc. I: Vita Philippi Dabralibanensis ad fidem manuscripti Orient. 728 Musei Britannici edita, Lipsia, 1902, p. 37.11-16.

14 Ibid., fasc. I, p. 42.15-17. 
the persecution of Däbrä Libanos took place, since Abbâ Honorius of Șəgağğa excommunicated the king 'Amdä Şyon, when he took the concubine of his father. There were those, who said that he fornicated with his sister, and those, who said

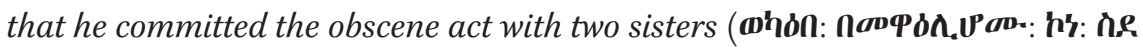

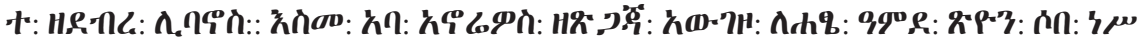

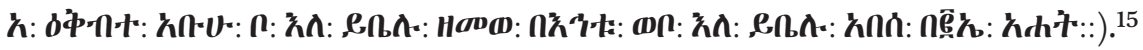

The cited information about the King 'Amdä Șəyon I's marriage and the acrimonious invectives sent by the monks leave no doubt that the direct quotation from the Scriptures it is thy father's nakedness (Lev. 18:8) in the Kabrä nägäst was transferred into an obvious allusion by intentional changes to it is thy mother's nakedness. Such an obvious change did support the accusation of the King 'Amdä Șəyon I of incest brought forward by the Ethiopian monks. Witty and intelligent, that allusion, however, could be understood by a very few people who received the traditional education and mastered the Ge'ez language. As a result the "defenders of Christian morals" committed a real falsification of the Holy Scripture for self-interested motives.

The above mentioned conflict between King 'Amdä Șəyon I and the Däbrä Libanos monastic congregation took place in the last years of his reign, i.e. somewhere between 1340 and 1345 . This short period can be justly considered as the terminus ante quem non for the final version of the Kabrä nägäśt.

15 R. Basset, "Études sur l'histoire d'Éthiopie," Journal Asiatique, $7^{\text {ème }}$ série, XVII (1881), p. 324.21-25. The French translation of that passage is not always exact (cf. R. Basset, "Études sur l'histoire d'Éthiopie," Journal Asiatique, $7^{\text {ème }}$ série, XVIII (1881), p. 93). 